\title{
IL-4-induced caveolin-1-containing lipid rafts aggregation contributes to MUC5AC synthesis in bronchial epithelial cells
}

Yu Xia ${ }^{1 \dagger}$, Peng-Cheng Cai ${ }^{2 \dagger}$, Fan Yu ${ }^{3}$, Liang Xiong ${ }^{3}$, Xin-Liang He ${ }^{3}$, Shan-Shan Rao ${ }^{1}$, Feng Chen ${ }^{4}$, Xiang-Ping Yang ${ }^{5}$, Wan-Li Ma ${ }^{3,6}$ and Hong Ye ${ }^{1,6^{*}}$

\begin{abstract}
Background: Mucus overproduction is an important feature of asthma. Interleukin (IL)-4 is required for allergeninduced airway inflammation and mucus production. MUC5AC gene expression is regulated by transcript factors NF-KB. The intracellular $\mathrm{Ca}^{2+}\left(\left[\mathrm{Ca}^{2+}\right]_{i}\right)$ signal is required for activation of NF-KB. The transient receptor potential canonical 1 (TRPC1) channel has been shown to contribute for agonist-stimulated $\mathrm{Ca}^{2+}$ influx in some types of cells. However, the relationships among IL-4, TRPC1 and mucus overproduction in bronchial epithelial cells (BECs) in asthma are poorly understood.

Methods: BECs were isolated from large bronchial airway of rats and used as cell model. To present changes of lipid raft, caveolin-1 and TRPC1, immunofluorescence staining and sucrose gradient centrifugation were performed. $\left[\mathrm{Ca}^{2+}\right]_{\mathrm{i}}$ was measured after loading with Fura-2. NF-kB activities were measured by an ELISA-based assay. MUC5AC mRNA and protein levels were detected by real-time quantitative RT-PCR, ELISA analysis and immunofluorescence staining respectively.

Results: IL-4 induced $\mathrm{Ca}^{2+}$ influx in BECs, and this was blocked by a $\mathrm{Ca}^{2+}$ influx inhibitor (2-APB). 2-APB also prevented MUC5AC protein synthesis induced by IL-4. Depletion of extracellular $\mathrm{Ca}^{2+}$ resulted in partial decrease in expression of MUC5AC in IL-4 treated cells. NF-KB rather than STAT6 activation mediated IL-4-induced MUC5AC protein synthesis. Then the mechanism of $\mathrm{Ca}^{2+}$ influx was investigated. Immunofluorescence staining and sucrose gradient centrifugation revealed that caveolin-1-containing lipid rafts aggregation was involved in TRPC1 activation and $\mathrm{Ca}^{2+}$ influx in BECs. Lastly, the data revealed that blocking lipid rafts aggregation exactly prevented $\mathrm{Ca}^{2+}$ influx, NF-kB activation and MUC5AC synthesis induced by IL-4.
\end{abstract}

Conclusions: Our results indicate that IL-4-induced caveolin-1-containing lipid rafts aggregation at least partly contributes to MUC5AC synthesis in BECs.

Keywords: IL-4, Bronchial epithelial cells, Lipid rafts, Intracellular Ca ${ }^{2+}$, MUC5AC, Asthma

\footnotetext{
* Correspondence: yehmwl@hust.edu.cn

${ }^{\dagger}$ Equal contributors

'Department of Pathophysiology, School of Basic Medicine, Tongji Medical

College, Huazhong University of Science and Technology, Wuhan, Hubei

430030, China

${ }^{6}$ Key Laboratory of Pulmonary Diseases, Ministry of Health of China, Wuhan,

Hubei, China

Full list of author information is available at the end of the article
} 


\section{Background}

Mucus overproduction is an important feature of asthma [1]. Excessive accumulation of airway mucus leads to the formation of mucous plugs that reduce the effective airway diameter and increase airway resistance. Mucins are glycoproteins that provide mucus with its viscoelasticity. MUC2, MUC4, MUC5AC, and MUC5B proteins are considered to be airway mucins. In asthma, there is over-expression of the major mucin glycoprotein, MUC5AC [2, 3].

Allergic pulmonary inflammation and airway hyperreactivity in most cases of asthma is closely related in $\mathrm{T}$ helper type 2 cells (Th2) responses [4]. Th2 cells predominantly secrete cytokines interleukin (IL)-4, IL-5, IL9 and IL-13, which play a central role in the pathophysiology of asthma. These type 2 cytokines are targets for pharmaceutical intervention of asthma. Studies showed that IL-4 is required for allergen-induced airway inflammation and mucus production [5-7]. MUC5AC expression is increased in mice over-expressing IL-4 compared to transgenic-negative control [7]. IL-4 binds to IL-4 receptor in airway cells and can trigger STAT6 and NF- $\mathrm{kB}$ signal pathway which is likely to be involved in the regulation of MUC5AC expression.

$M U C 5 A C$ gene expression is regulated by transcript factors NF-kB and STAT6 [8-10]. NF-kB is involved in cytokine-induced MUC5AC expression. IL-17 promoted NF- $\mathrm{kB}$ translocation which subsequently binds to the NF$\kappa \mathrm{B}$-binding sequences of the $M U C 5 A C$ promoter, and leads to up-regulation of MUC5AC expression in human bronchial epithelial cells $[11,12]$. The intracellular $\mathrm{Ca}^{2+}$ $\left(\left[\mathrm{Ca}^{2+}\right]_{\mathrm{i}}\right)$ signal is required for activation of NF-kB $[13,14]$ and subsequently regulates downstream gene expression. But how $\mathrm{Ca}^{2+}$ signal is triggered under pathophysiological conditions remains poorly understood.

Transient receptor potential canonical 1 (TRPC1) is a transmembrane protein expressed in a range of vertebrate cells. TRPC1 channel has been shown to contribute to agonist-stimulated $\mathrm{Ca}^{2+}$ influx in salivary cells and pancreatic acinar cells [15-17]. Extensive studies have confirmed the contribution of TRPC1 to store-operated $\mathrm{Ca}^{2+}$ entry (SOCE). The interaction between TRPC1 and the key components of SOCE, STIM1, and Orail determines the activation of TRPC1 [18]. TRPC1 is sub-cellular compartmentalised, at least in part in cholesterol-rich caveolae.

Plasma membrane lipid rafts domains (LRD), which contain high concentrations of cholesterol and sphingolipids, are known to function as centers for the assembly of signaling complexes. Such assembly is known to regulate cellular functions such as transcytosis, protein sorting, cell adhesion and migration as so on. Lipid rafts aggregation facilitate the formation of the STIM1-Orai1TRPC1 complex and the activation of SOCE [19]. Caveolin-1, a cholesterol-binding protein is involved in the generation of caveolar lipid rafts. The agoniststimulated $\mathrm{Ca}^{2+}$ signals have been shown to originate at caveolin-1 enriched plasma membrane regions [20-23]. In asthma, there are increases in the number of mucusproducing goblet cells in airway epithelium [24]. The bronchial epithelial cell (BEC) is also one of important cell types that produce mucus production [25]. However, the role of lipid rafts/TRPC1 and $\mathrm{Ca}^{2+}$ influx in BECs of asthma is unknown.

We hypothesized here that IL-4 increased BECs MUC5AC gene expression through lipid rafts aggregation and TRPC1 channel activation. In the current study, we found that IL-4 caused caveolin-1 containing lipid rafts aggregation and TPRC1 colocalization, and disruption of lipid rafts prevented IL-4 induced NF- $\kappa B$ activation and MUC5AC expression.

\section{Methods}

\section{Reagents and materials}

Methyl- $\beta$-cyclodextrin (M- $\beta C D)$, 2-Aminoethyl diphenylborinate (2-APB), ethylene glycol tetraacetic acid (EGTA) and Pronase E were purchased from SigmaAldrich (St. Louis, MO, USA). Epithelial cell medium was obtained from Cell Biologics (Chicago, IL, USA). IL4 was obtained from Pepro Tech (Rocky Hill, NJ, USA). Anti-caveolin-1 antibody was purchased from BD Transduction Laboratories (Lexington, KY, USA), rabbit antiTRPC1 polyclonal antibody was purchased from Abcam (Cambridge, UK), anti-P65 antibody was purchased from Santa Cruz Biotechnology (Santa Cruz, CA, USA). Cholera toxin subunit B-Alexa Fluor 488 and Trizol Reagent were obtained from Life Technology (Grand Island, NY, USA). Fura-2-AM was purchased from Dojindo laboratories (Kumamoto, Japan). MUC5AC ELISA kit was obtained from Cloud-Clone Corp (Wuhan, China). Anti-MUC5AC antibody was purchased from Absin (Shanghai, China). Antibodies against $\beta$-actin, p-STAT6 and p-P65 were purchased from Cell Signaling Technology (Danvers, MA, USA). Specific STAT6 inhibitor AS1517499 and selective IKB kinase (IKK) inhibitor IKK16 was purchased from MedChem Express (Monmouth Junction, NJ, USA).

\section{Isolation and primary culture of rat BECs}

BECs were isolated from large bronchial airway of rat as described in the literature [26]. The experiments were performed in accordance with the Guide for the Care and Use of Laboratory Animals and approved by the Institutional Animal Care and Use Committee (IACUC) of the Tongji Medical College, Huazhong University of Science and Technology. In brief, airway was isolated from rat under sterile conditions, rinsed with ice D-Hanks twice, then digested with $1 \%$ Pronase E in DMEM/F-12 at $4^{\circ} \mathrm{C}$ for $14 \mathrm{~h}$. Then BECs were harvested with ice Dhanks contain 5\% newborn bovine serum (NBS) and 
centrifuged at $1000 \mathrm{rpm}$ for $5 \mathrm{~min}$. The spun down cells were resuspended with epithelial cell medium (Cell Biologics, Chicago, IL, USA) and incubated in a $5 \% \mathrm{CO}_{2}$ incubator (Thermo Fisher Forma, Waltham, MA, USA) at $37{ }^{\circ} \mathrm{C}$. These cells were used in experiments without subculture. In most experiments, BECs were treated by the indicated factors in serum-free medium when the cells were $60-70 \%$ confluence. For MUC5AC immunostaining, the isolated cells digested with protease were cultured on cover slip with serum-containing medium for $24 \mathrm{~h}$ in the Petri dish. Some digested cells were presented as small clusters, but not completely separated cells. IL-4 containing serum-free medium was administered when the cells reached about $30 \%$ confluence.

\section{$\left[\mathrm{Ca}^{2+}\right]_{\mathrm{i}}$ measurements}

BECs $\left[\mathrm{Ca}^{2+}\right]_{\mathrm{i}}$ were measured after loading with $10 \mu \mathrm{M}$ of the acetoxymethyl ester form of Fura- 2 for $30 \mathrm{~min}$ at room temperature. Then, the fluorescence of Fura- 2 was

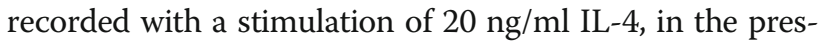
ence or absence of $10 \mathrm{mM} \mathrm{M}-\beta C D$ or $50 \mu \mathrm{M} 2$-APB after excitation at $340 \pm 10$ and $380 \pm 10 \mathrm{~nm}$ using a xenon short-arc lamp (Ushio). Bandpass interference filters (Omega Optical, Brattleboro, VT 05301) selected wavelength bands of emitted fluorescence at $510 \pm 10 \mathrm{~nm}$. In the process of $\left[\mathrm{Ca}^{2+}\right]_{\mathrm{i}}$ measurements, we firstly got stable $\left[\mathrm{Ca}^{2+}\right]_{\mathrm{i}}$ signal, $250 \mathrm{~s}$ later, we treated cells with 2-APB or IL-4. M- $\beta C D$ was used before $\left[\mathrm{Ca}^{2+}\right]_{\mathrm{i}}$ measurements. In some experiments, we firstly treated cells with $2-\mathrm{APB}$ or M- $\beta C D$, then added IL- 4 to the cells at 1800 s. Emitted Fura-2 fluorescence was collected and measured using a spectrofluorometer (PTI, Deltascan).

To acquire the final $\left[\mathrm{Ca}^{2+}\right]_{\mathrm{i}}$ with the ratios from Fura-2 fluorescence, we had detected the minimum and maximum Fura-2 fluorescence ratio $\left(\mathrm{R}_{\min }\right.$ and $\left.\mathrm{R}_{\max }\right)$ with $\mathrm{Ca}^{2}$ ${ }^{+}$-free buffer without calcium $(8.182 \mathrm{~g} \mathrm{NaCl}, 0.335 \mathrm{~g} \mathrm{KCl}$, 0.385 g EGTA, 2 g Glucose, 1.2 g HEPES, $0.2 \mathrm{~g} \mathrm{MgCl}_{2}, 1 \mathrm{~L}$ $\left.\mathrm{H}_{2} \mathrm{O}, \mathrm{PH} 7.4\right)$ and $\mathrm{Ca}^{2+}$-high buffer with high concentration of $\mathrm{Ca}^{2+}\left(8.182 \mathrm{~g} \mathrm{NaCl}, 0.335 \mathrm{~g} \mathrm{KCl}, 0.555 \mathrm{~g} \mathrm{CaCl}_{2}, 2 \mathrm{~g}\right.$ Glucose, $1.2 \mathrm{~g}$ HEPES, $0.2 \mathrm{~g} \mathrm{MgCl}_{2}, 1 \mathrm{~L} \mathrm{H}_{2} \mathrm{O}$, PH7.4). The $\mathrm{R}_{\text {min }}$ was determined using $\mathrm{Ca}^{2+}$-free buffer and stimulated by $3 \mu \mathrm{M}$ ionomycin (Sigma). The same to $R_{\min }$, the $\mathrm{R}_{\max }$ was measured with $\mathrm{Ca}^{2+}$-high buffer and stimulated by $3 \mu \mathrm{M}$ ionomycin. The final $\left[\mathrm{Ca}^{2+}\right]_{\mathrm{i}}$ was calculated with $\mathrm{R}_{\min }$ and $\mathrm{R}_{\max }$ follow this equation: $\left[\mathrm{Ca}^{2+}\right]_{i}=\mathrm{Kd} \mathrm{\beta}^{*}(\mathrm{R}-$ $\left.R_{\min }\right) /\left(R_{\max }-R\right), K d$ is a constant which is 224 for BECs, and the $\beta$ values is the fluorescence intensity emitted by $380 \pm 10 \mathrm{~nm}$ within $\mathrm{Ca}^{2+}$-free buffer. $\mathrm{Ca}^{2+}$ influx duration was calculated from the beginning of $\mathrm{Ca}^{2+}$ level rise to the time of $\mathrm{Ca}^{2+}$ level return to the base.

\section{NF-kB activity assay}

An ELISA-based assay was performed to measure endogenous NF- $\mathrm{kB}$ activities as described previously [27]. Briefly, after BECs were treated with $20 \mathrm{ng} / \mathrm{ml} \mathrm{IL}-4$ for $24 \mathrm{~h}$ in the presence or absence of $\mathrm{M}-\beta \mathrm{CD}$ or $2-\mathrm{APB}(\mathrm{M}-\beta \mathrm{CD}$ or 2APB was administrated half an hour before IL-4 using), the cells were lysed with lysis buffer (20 mM HEPES pH 7.5, $0.35 \mathrm{M} \mathrm{NaCl}, 20 \%$ glycerol, $1 \% \mathrm{NP}-40,1 \mathrm{mM} \mathrm{MgCl} 2 \cdot 6 \mathrm{H}_{2} \mathrm{O}$, $0.5 \mathrm{mM}$ EDTA, $0.1 \mathrm{mM}$ EGTA) containing a protease inhibitor cocktail (Calbiochem, La Jolla, CA, USA) on ice for $10 \mathrm{~min}$. The supernatant obtained after centrifugation at $14,000 \mathrm{rpm}$ for $30 \mathrm{~min}$ at $4{ }^{\circ} \mathrm{C}$ was recovered. The doublestranded probe with single-stranded-linker was generated by $1: 1 \mathrm{mix}$ of the following two oligonucleotide with the sequences of 5 '-AGTTGAGGGGACTTTCCCAGGCC(C)34-C-3', the $3^{\prime}$ end biotinylated and $5^{\prime}$-GCCT GGGAAAGTCCCCTCAACT-3', respectively. The probe was denatured at $94{ }^{\circ} \mathrm{C}$ for $10 \mathrm{~min}$, annealed at room temperature overnight and then linked to streptavidincoated 96-well plates (Roche, Mannheim, Germany) by incubating 2 pmol of probe per well for $1 \mathrm{~h}$ at $37^{\circ} \mathrm{C}$ in $50 \mu \mathrm{l}$ PBS. After wash, $20 \mu \mathrm{l}$ of cell extract were mixed with $30 \mu \mathrm{l}$ of binding buffer (4 mM HEPES pH 7.5, $100 \mathrm{mM}$ $\mathrm{KCl}, 8 \%$ glycerol, $5 \mathrm{mM}$ DTT, $0.2 \% \mathrm{BSA}, 40 \mu \mathrm{g} / \mathrm{ml}$ salmon sperm DNA) in the above microwells incubated at room temperature with mild agitation $(200 \mathrm{rpm})$ for $1 \mathrm{~h}$. After wash, mouse anti-NF-kB p65 monoclonal antibody (1:1000 diluted) was incubated for $1 \mathrm{~h}$ at room temperature. After wash, peroxidase-conjugated goat antimouse IgG were incubated at room temperature for $1 \mathrm{~h}$. After wash, $100 \mu \mathrm{l}$ tetramethylbenzidine was incubated at room temperature for $10 \mathrm{~min}$ before adding $100 \mu \mathrm{l}$ of stopping solution $\left(2 \mathrm{M} \mathrm{H}_{2} \mathrm{SO}_{4}\right)$. Optical density was then read at $450 \mathrm{~nm}$ under a microplate reader (Biotek Instruments, Winooski, VT, USA) using a 655 -nm reference wavelength. Backgrounds are determined in lysis buffer and subtracted before data analysis.

\section{Real-time quantitative RT-PCR (qRT-PCR) analysis for MUC5AC mRNA levels}

Total RNA was extracted from BECs using Trizol Reagent. cDNAs were synthesized from total RNA by reverse transcription according to the manufacturer's instruction. Then $\mathrm{cDNAs}$ were used for amplification by qRT-PCR in a $25 \mu \mathrm{l}$ reaction using $\mathrm{SYBR}^{\circ}$ Premix EX $\mathrm{Taq}^{\mathrm{Tm}}$ II (TaKaRa) with a Mini Opticon Real-time PCR Systerm (BIORAD). MUC5AC mRNA expression was normalized with $\beta$-actin. The MUC5AC primers were $F$ : 3-GCTCATCCTAA GCGACGTCT-5, R: 3-GGGGGCA TAACTTCTCTTGG-5, and the $\beta$-actin primers were F: 3-CGGCATTGTCACCAACTG-5, R: 3-CGCTCGGTCA GGATCTTC-5.

\section{ELISA analysis for MUC5AC protein levels}

Intracellular MUC5AC protein levels were measure using ELISA kits following the manufacturer's instructions (Cloud-Clone Corp, Wuhan, China). 
Immunofluorescence staining and confocal microscopy To determine the protein level of MUC5AC, BECs were cultured on cover slips, after pretreated with EGTA $(0.5 \mathrm{mM}, 2 \mathrm{mM}$ or $5 \mathrm{mM})$, AS1517499 or LKK16 for $30 \mathrm{~min}$, cells were treated with IL-4 (20 ng/ml). $24 \mathrm{~h}$ later, BECs were stained with rabbit anti-MUC5AC antibody (1:100 dilution) at $4{ }^{\circ} \mathrm{C}$ overnight, and then incubated with tetramethyl rhodamin isothiocyanate (TRITC)-conjugated goat anti-rabbit antibody at room temperature for $60 \mathrm{~min}$. The nuclei were stained for DAPI for $10 \mathrm{~min}$ in dark. The fluorescence-labeled cells were examined using a Zeiss-LSM780 Confocal laser scanning microscope (Oberkochen, German).
To determine the protein level of caveolin-1 and TRPC1, as well as lipid rafts aggregation, BECs were cultured on cover slips, after pretreated with $10 \mathrm{mM} \mathrm{M}$ $\beta C D$ or $100 \mu \mathrm{M} 2$-APB for $30 \mathrm{~min}$, cells were treated with $20 \mathrm{ng} / \mathrm{ml} \mathrm{IL-4}$ for $15 \mathrm{~min}$ in the presence or absence of $\mathrm{M}-\beta C D$ or $2-\mathrm{APB}, \mathrm{BECs}$ were stained with a mouse monoclonal antibody specific to caveolin-1 and rabbit anti-TRPC1 polyclonal antibody. Lipid rafts were visualized by staining with $2 \mu \mathrm{g} / \mathrm{ml}$ cholera toxin subunit B- Alexa Fluor 488 for 20 min.

Flotation of lipid rafts by sucrose gradient centrifugation To isolate lipid raft fractions from the cell membrane, BECs were lysed in $1.5 \mathrm{ml}$ buffer containing $10 \mathrm{mM}$
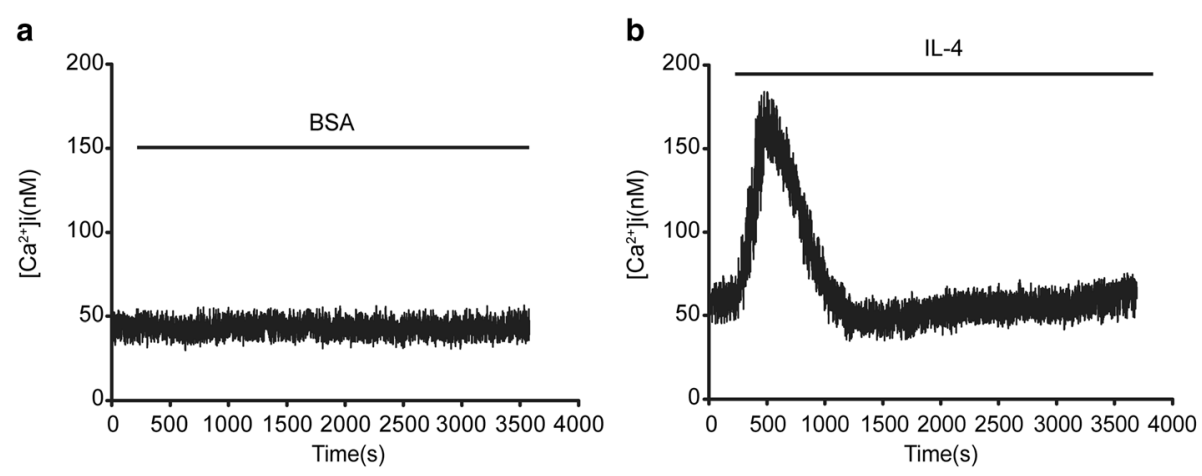

C

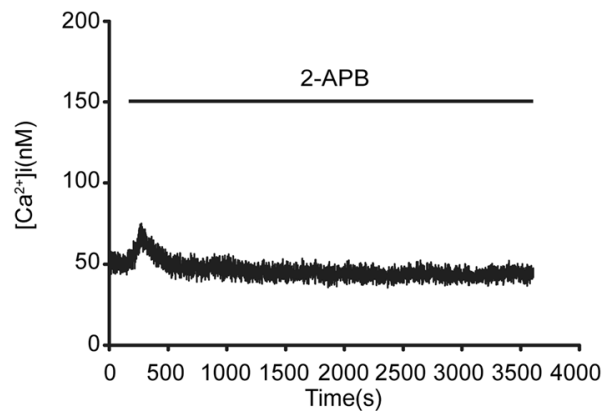

e

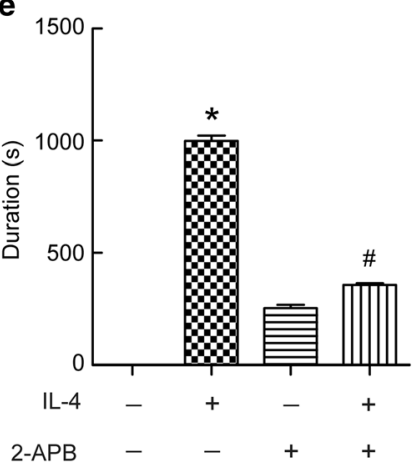

d
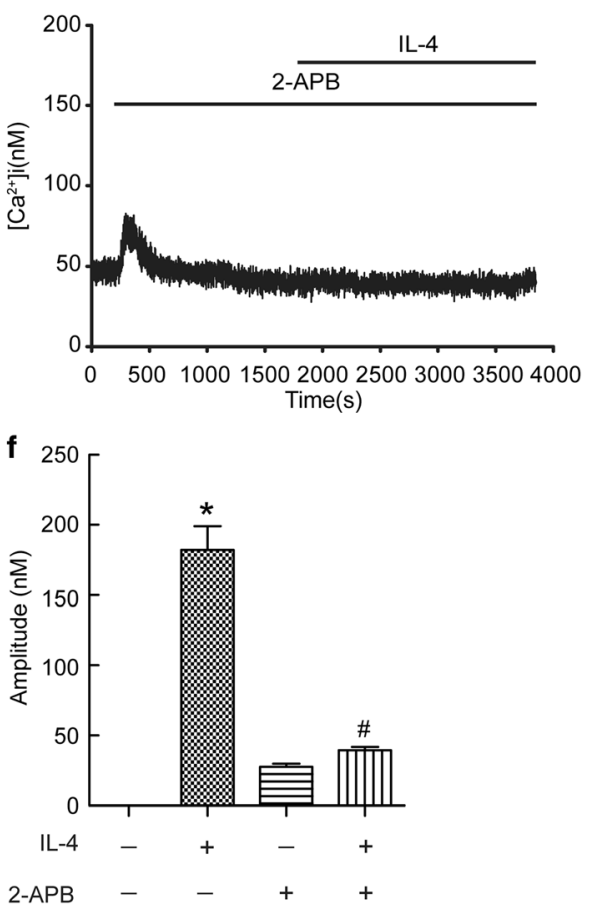

Fig. $12-A P B$ prevented IL-4-induced $\mathrm{Ca}^{2+}$ influx in BECs. Intracellular $\mathrm{Ca}^{2+}\left(\left[\mathrm{Ca}^{2+}\right]_{\mathrm{i}}\right)$ levels were recorded using Fura-2/AM. The fluorescence of Fura-2 was detected in cells with a stimulation of $\mathrm{IL}-4(20 \mathrm{ng} / \mathrm{ml})$ in the presence or absence of $50 \mu \mathrm{M} 2$-APB. Ca ${ }^{2+}$ signals were recorded for the calculation of fluorescence intensity ratio of F340/F380. (a-d) Representative traces of calcium responses. (e and $\mathbf{f}$ ) Changes in duration and amplitude of $\left[\mathrm{Ca}^{2+}\right]_{\mathrm{i}}$. Results are expressed as mean $\pm \mathrm{SD} ; n=10 .{ }^{*} P<0.05$ versus $\mathrm{BSA},{ }^{\#} P<0.05$ versus IL-4 treated group 
Tris. $\mathrm{HCl}, 150 \mathrm{mM} \mathrm{NaCl}, 5 \mathrm{mM}$ EDTA, $1 \mathrm{mMPMSF}$, $3 \mathrm{mM} \mathrm{Na}_{3} \mathrm{VO}_{4}$, protease inhibitors cocktail and 1\% Triton X-100 ( $\mathrm{pH}$ 7.4). Cell extracts were homogenized with five passages through a 25 -gauge needle. Homogenates were adjusted with $60 \%$ sucrose density gradient medium to $40 \%$ and overlaid with $2 \mathrm{ml} 90 \%$ sucrose, $4 \mathrm{ml} 35 \%$ sucrose and $4 \mathrm{ml} 5 \%$ sucrose Density Gradient medium gently.

Samples were centrifuged at $39000 \mathrm{rpm}$ and $4{ }^{\circ} \mathrm{C}$ for $18 \mathrm{~h}$ using a SW32.1 rotor. Fractions were collected from top to bottom, each sample had 11 fractions. For immunoblot analysis of lipid raft-associated proteins, these fractions were precipitated by mixing with equal volume of $100 \%$ trichloroacetic acid and 30 min of incubation on ice, and then samples were centrifuged at $15000 \mathrm{~g}$ and $4^{\circ} \mathrm{C}$ for $15 \mathrm{~min}$, protein sediments were washed with ice acetone twice, air dried, and then resuspended in $1 \mathrm{M}$ Tris. $\mathrm{HCl}(\mathrm{pH} 8.0)$, which was ready for immunoblot analysis. Western blots were performed to detect protein levels of caveolin-1 and TRPC1 in each fraction.

\section{Statistical analysis}

Results are shown as the mean \pm SD for $\mathrm{n}$ experiments, $\mathrm{n}$ means cells from $\mathrm{n}$ rats. Differences between groups were analyzed using unpaired $t$ tests or two-way analysis of variance. A $P$ value less than 0.05 was considered to be statistically significant.

\section{Results}

2-APB prevented IL-4-induced $\mathrm{Ca}^{2+}$ influx in BECs

To study the effect of IL-4 on $\left[\mathrm{Ca}^{2+}\right]_{i}$ in BECs, we treated BECs with IL-4 in the presence or absence of 2APB, an inhibitor of $\mathrm{Ca}^{2+}$ release. As shown in Fig. 1a-d,
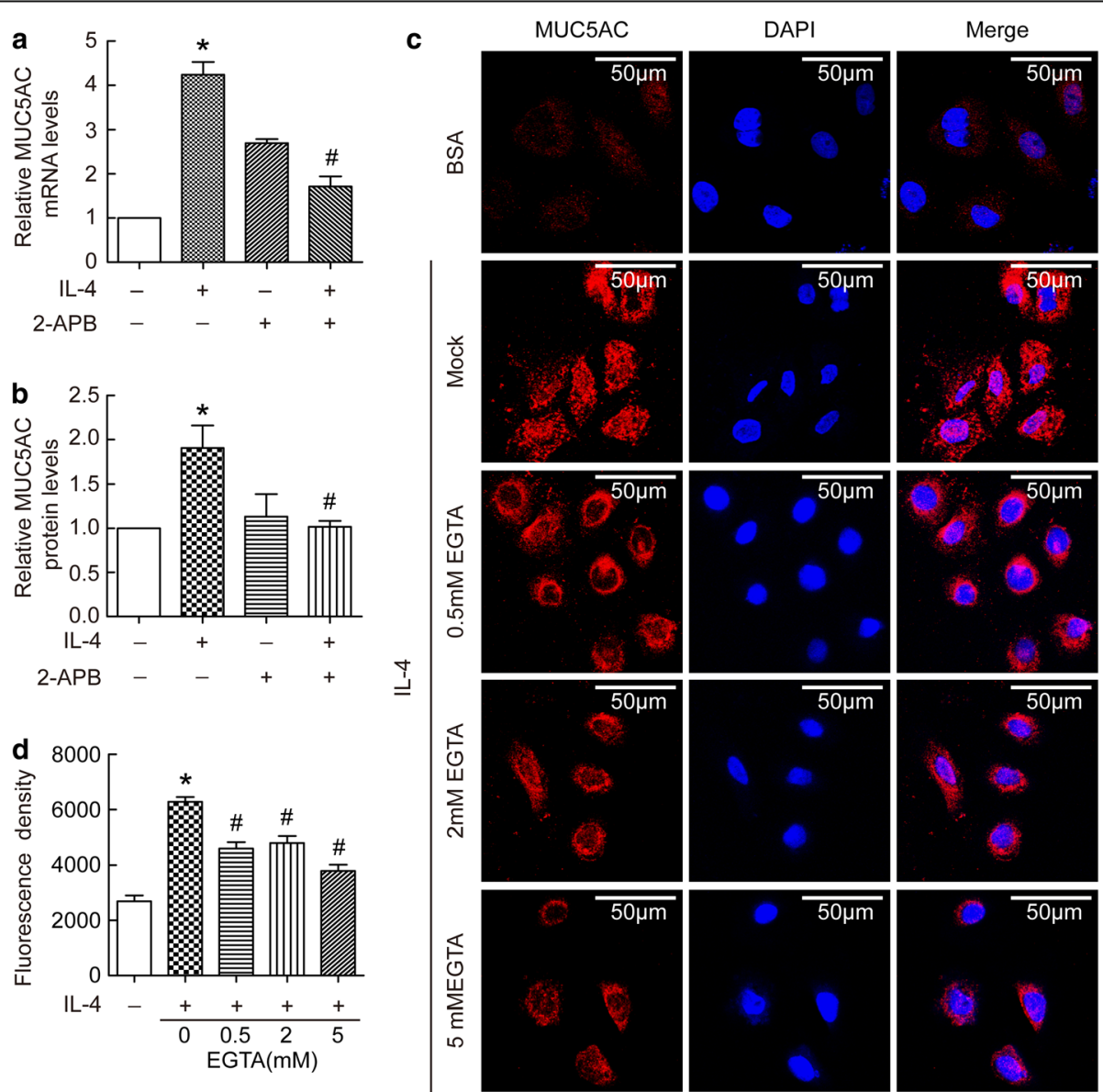

Fig. 2 Extracellular $\mathrm{Ca}^{2+}$ signal mediated IL-4-induced MUC5AC protein synthesis in BECs. (a and b) BECs were treated with $20 \mathrm{ng} / \mathrm{ml} \mathrm{IL}-4 \mathrm{for} 24 \mathrm{~h}$ in the presence or absence of $50 \mu \mathrm{M}$ 2-APB. Then cell lysates were prepared for the determination of intracellular MUC5AC mRNA and protein levels. Results are expressed as mean \pm SD; $n=4$ experiments. ${ }^{*} P<0.05$ versus normal control, ${ }^{\#} P<0.05$ versus IL-4 treated group. (c and $\mathbf{d}$ ) BECS were pretreated with $0 \mathrm{mM}, 0.5 \mathrm{mM}, 2 \mathrm{mM}$, or $5 \mathrm{mM} \mathrm{EGTA}$ for half an hour, and then treated for $24 \mathrm{~h}$ in the presence or absence of $20 \mathrm{ng} / \mathrm{ml} \mathrm{IL}-$ 4. Immunofluorescence staining of MUC5AC protein was performed according to the Methods. Representative staining is shown in the $\mathbf{c}$, and immunofluorescence density is shown in the $\mathbf{d}$. Results are expressed as mean \pm SD; $n=21$ (cells). ${ }^{*} P<0.05$ versus normal control, ${ }^{\#} P<0.05$ versus IL-4 treated group 
IL-4 significantly increased the level of $\left[\mathrm{Ca}^{2+}\right]_{\mathrm{i}}$, but this was abolished by 2-APB. After careful analysis of $\mathrm{Ca}^{2+}$ influx duration and amplitude, we found both $\mathrm{Ca}^{2+}$ influx duration and amplitude were increased with the treatment of IL-4 in BECs (Fig. 1e, f). These data suggested that IL-4 induced $\mathrm{Ca}^{2+}$ influx could be prevented by 2 -APB in BECs.

\section{Extracellular $\mathrm{Ca}^{2+}$ signal mediated IL-4-induced MUC5AC protein synthesis in BECs}

To investigate the role of $\mathrm{Ca}^{2+}$ influx in MUC5AC synthesis, we detected MUC5AC mRNA and protein levels in BECs treated by IL-4. As shown in Fig. 2a and b, IL-4 increased the levels of MUC5AC mRNA and protein expression, and these were prevented by 2-APB (Fig. 2a, b). Because 2-ABP is nonspecific and blocks both TRP channels and intracellular inositol triphosphate receptor (IP3R), to distinguish between extracellular and intracellular $\mathrm{Ca}^{2+}$ source, we blocked extracellular $\mathrm{Ca}^{2+}$ using EGTA. As shown in Fig. 2c and d, IL-4 induced increases in MUC5AC expression, but this was attenuated by EGTA at a dose-dependent manner. These data suggested extracellular $\mathrm{Ca}^{2+}$ influx played a role in $\mathrm{IL}-4$ induced MUC5AC expression.

\section{NF-KB rather than STAT6 activation mediated IL-4- induced MUC5AC protein synthesis}

To study downstream signals of IL-4 in BECs, we investigate STAT6 and NF- $\mathrm{kB}$ pathways. As shown in Fig. 3a and $\mathrm{b}, \mathrm{IL}-4$ induced time-dependent phosphorylation of STAT6 and P65 which suggested both signals were activated in IL-4 treated BECs. To further distinguish the role of STAT6 and NF-kB pathway in IL-4-induced MUC5AC expression, we used specific STAT6 inhibitor AS1517499 and a selective IKB kinase (IKK) inhibitor IKK 16 to treat cells. As shown in Fig. 3c, IKK 16 induced significant down-regulation of MUC5AC protein, but AS1517499 had no effect on IL-4 induced upregulation of MUC5AC protein. These data suggested that NF- $\mathrm{kB}$ rather than STAT6 signal pathway mediated MUC5AC up-regulation induced by IL-4. To further dissect the role of NF-kB as well as the relationship with $\mathrm{Ca}^{2+}$ influx, we detected NF- $\mathrm{kB}$ activity. As shown in Fig. 3d, IL-4 enhanced NF-kB activity, and this was
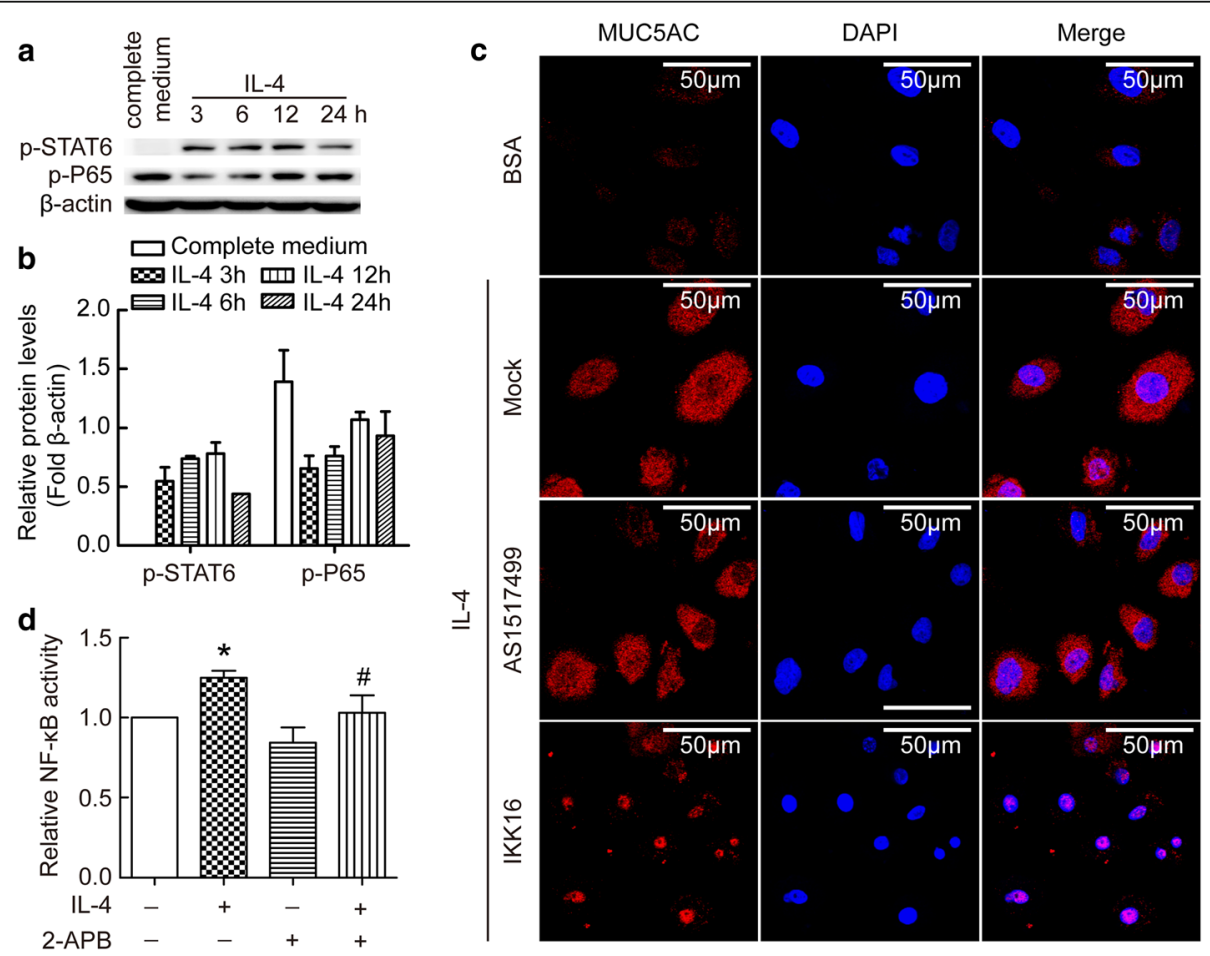

Fig. 3 NF-KB rather than STAT6 activation mediated IL-4-induced MUC5AC protein synthesis in BECs. BECs were treated with IL-4 (20 ng/ml) for 3 , 6,12 , or $24 \mathrm{~h}$. The complete cell-cultured medium was used as control. Intracellular p-STAT6 and p-P56 proteins were measured by Western blot. (a) Representative image of immunoblots of p-STAT6 and p-P56. (b) Bar graph depicting changes in relative density of p-STAT6 and p-P56 according to $\mathbf{a}$. (c) BECS were pretreated with specific STAT6 inhibitor (AS1517499) or a selective IKB kinase inhibitor (IKK 16) for half an hour, then treated for $24 \mathrm{~h}$ in the presence or absence of $20 \mathrm{ng} / \mathrm{ml} \mathrm{IL-4}$. Immunofluorescence staining of MUC5AC protein was performed according to the Methods. Representative staining is shown in the c. (d) BECs were treated with $20 \mathrm{ng} / \mathrm{ml} \mathrm{IL-4}$ for $24 \mathrm{~h}$ in the presence or absence of $50 \mu \mathrm{M}$ 2-APB. Then cell lysates were used to detect endogenous NF-KB transcriptional activity. Results are expressed as mean \pm SD; $n=4$ experiments. ${ }^{*} P<0.05$ versus normal control, ${ }^{\#} P<0.05$ versus $\mathrm{IL}-4$ treated group 
blocked by 2-APB. These data suggested extracellular $\mathrm{Ca}^{2+}$ influx played a role in IL-4 induced NF- $\mathrm{kB}$ activation and further MUC5AC expression.

\section{Caveolin-1 containing lipid rafts aggregation was involved in TRPC1 activation by IL-4 in BECs}

To explore the potential mechanism underlying extracellular $\mathrm{Ca}^{2+}$ influx induced by IL-4, we next focused on the lipid rafts clustering in BECs. We detected the colocalization and clustering of caveolin-1 and ganglioside GM1 enriched lipid rafts. Cells were first incubated with an anti-calveolin-1 antibody, followed by staining with cholera toxin subunit B-Alexa Fluor 488, which is a specific clustering agent for GM1 enriched lipid rafts. As shown in Fig. 4a and b, IL-4 induced clustering and colocalization of GM1 enriched lipid rafts and caveolin1 . Moreover, when the cells were treated with the inducer of lipid rafts disruption (M- $\beta C D)$, IL-4 failed to induce clustering of lipid rafts. By using sucrose gradient ultracentrifugation and immunoblotting, lysates were separated into lipid raft and non-lipid raft fractions. As shown in Fig. 4c, caveolin-1 was mainly found in nonlipid raft fractions in the control. However, the treatment of IL-4 led to significantly increased caveolin-1 in lipid raft fractions, and this was prevented by $\mathrm{M}-\beta C D$ (Fig. 4c, d). These data suggested that IL-4 induced caveolin-1 containing lipid rafts aggregation.

TRPC activation is necessary in extracellular $\mathrm{Ca}^{2+}$ influx when IP3 binds with IP3R, so to further uncover the relationship between extracellular $\mathrm{Ca}^{2+}$ influx and caveolin-1-containing lipid rafts aggregation, we studied the colocalization of TRPC1 and caveolin-1. As shown in Fig. 4e and f, IL-4 induced clustering and colocalization of caveolin-1 and TRPC1. After sucrose gradient ultracentrifugation, the immunoblotting images revealed that TRPC1 was found in non-lipid raft fractions in
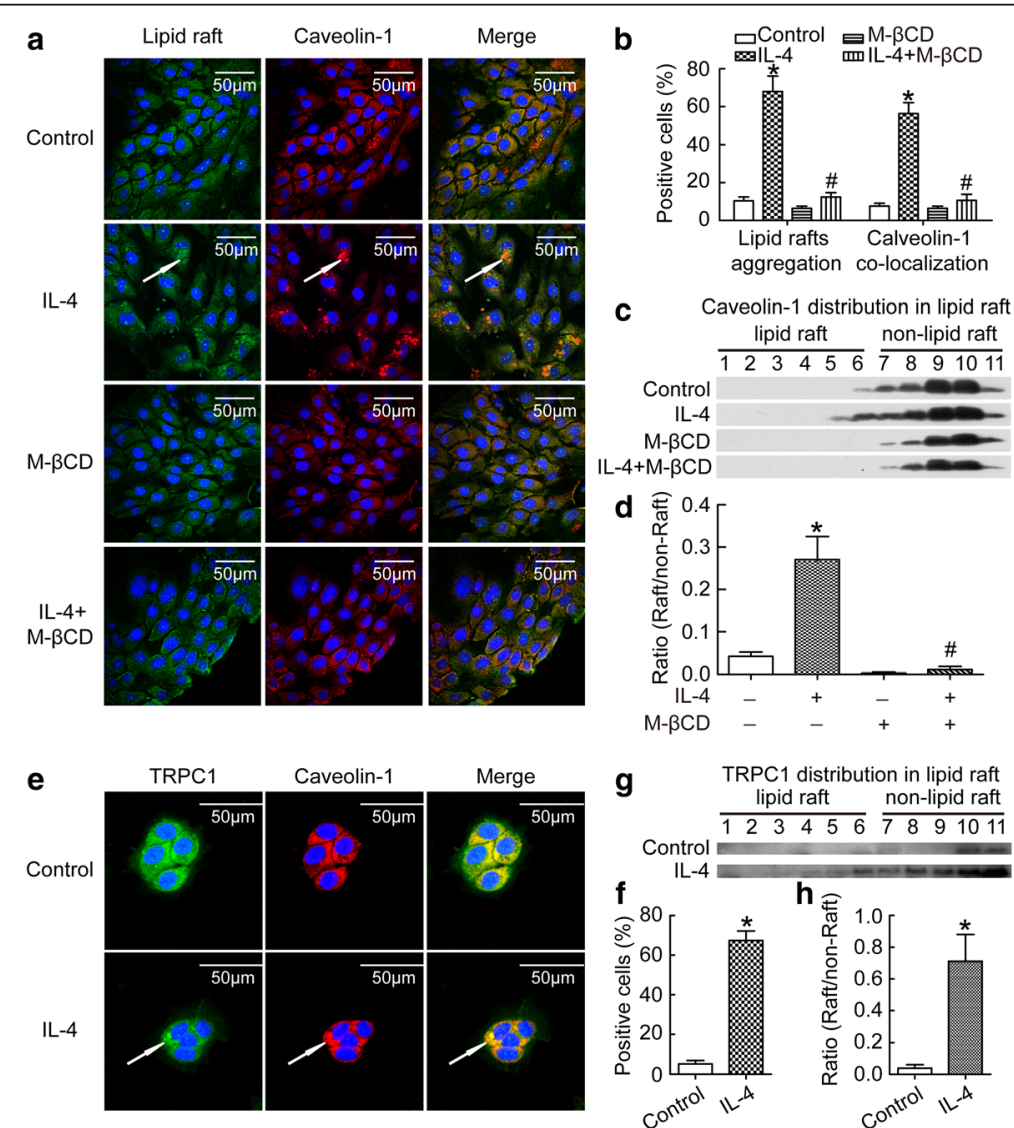

Fig. 4 IL-4 induced caveolin-1-containing lipid rafts aggregation and TRPC1 activation. BECs were treated with 20 ng/ml IL-4 for 24 h, then intracellular co-localization of caveolin-1 and lipid rafts were detected with immunofluorescence (a); the percents of positive lipid rafts aggregation cells and caveolin-1 co-localization cells were calculated (b); caveolin-1 distribution in lipid raft were measured by sucrose gradient centrifugation (c); the ratio of caveolin-1 distribution in lipid raft to non-lipid raft was evaluated (d); intracellular co-localization of caveolin-1 and TRPC1 were detected with immunofluorescence (e); the percents of positive TRPC1 and caveolin-1 co-localization cells were calculated (f); TRPC1 distribution in lipid raft was measured by sucrose gradient centrifugation (g); the ratio of TRPC1 distribution in lipid raft to non-lipid raft was evaluated (h). White arrow (in $\mathbf{a}$ and $\mathbf{e}$ ) indicated lipid rafts aggregation, calveolin-1 aggregation, or TRPC1 aggregation as well as their co-localization respectively. Results are expressed as mean $\pm \mathrm{SD} ; n=4$ experiments. ${ }^{*} P<0.05$ versus normal control, ${ }^{\#} P<0.05$ versus IL-4 treated group 
normal control, but IL-4 caused significant increase of TRPC1 in lipid raft fractions (Fig. 4g, h). These data suggested that IL-4 induced colocalization of TRPC1 in caveolin-1-containing lipid rafts aggregation.

\section{Blocking lipid rafts aggregation prevented extracellular $\mathrm{Ca}^{2+}$ influx induced by IL-4}

To further confirm the colocalization of TRPC1 in caveolin-1-containing lipid rafts aggregation, we detected $\left[\mathrm{Ca}^{2+}\right]_{\mathrm{i}}$ levels. BECs were exposed to $\mathrm{IL}-4$ in the presence or absence of M- $\beta C D$. As shown in Fig. 5, IL-4 triggered increases in $\left[\mathrm{Ca}^{2+}\right]_{\mathrm{i}}$ including amplitude and duration, but after disruption of lipid raft clustering with $M-\beta C D$, IL-4 did not induce any change in $\left[\mathrm{Ca}^{2+}\right]_{\mathrm{i}}$ signal. These data suggested that IL-4 induced intracellular calcium response is mediated by lipid rafts aggregation.

\section{Caveolin-1-containing lipid rafts aggregation induced by IL-4 contributed to MUC5AC synthesis}

To study the role of IL-4-induced caveolin-1-containing lipid rafts aggregation in MUC5AC synthesis in BECs, we used $M-\beta C D$ to disrupt lipid rafts aggregation, and then detected changes in NF- $\mathrm{KB}$ activity and MUC5AC levels. As shown in Fig. 6a, IL-4 induced increases in NF- $\mathrm{KB}$ activity, and this was blocked by M- $\beta C D$. IL- 4 significantly increased the intracellular MUC5AC mRNA and protein levels (Fig. 6b, c), disruption of lipid raft by

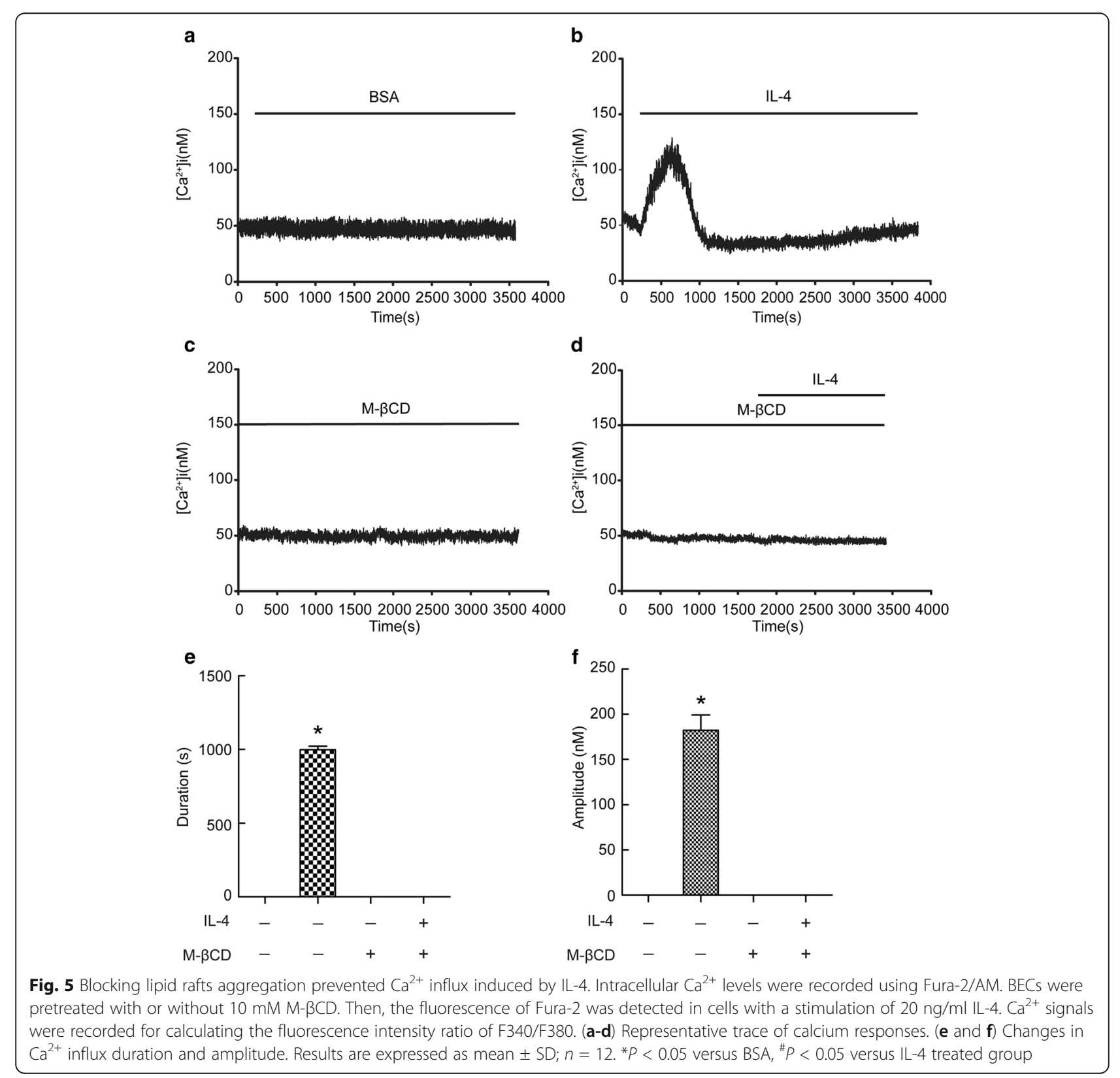



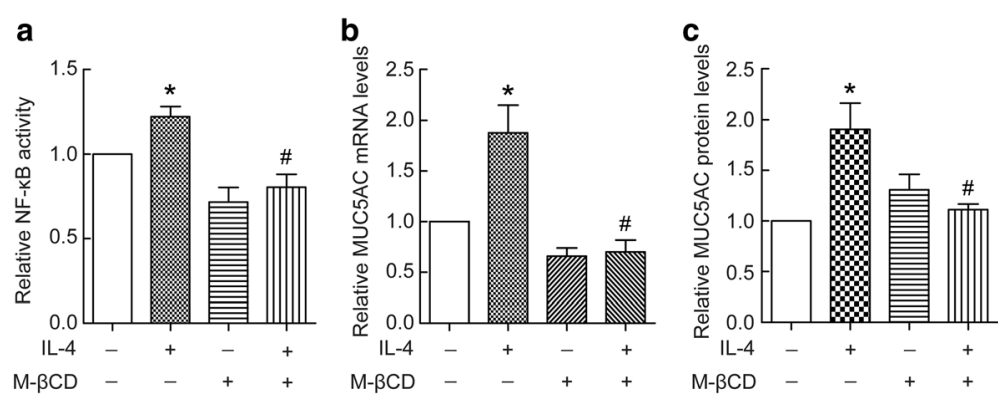

Fig. 6 Caveolin-1-containing lipid rafts aggregation by IL-4 contributed to MUC5AC synthesis. BECs were treated with $20 \mathrm{ng} / \mathrm{ml}$ IL-4 for $24 \mathrm{~h}$ in the presence or absence of $10 \mathrm{mM} \mathrm{M- \beta CD}$. Then, cell lysates were prepared for determination of endogenous NF-kB transcriptional activity (a), and intracellular MUC5AC mRNA and protein levels (b and $\mathbf{c}$ ). Results are expressed as mean $\pm \mathrm{SD} ; n=4$ experiments. ${ }^{*} P<0.05$ versus normal control, $"$ P $<0.05$ versus IL-4 treated group

M- $\beta C D$ attenuated IL-4-induced increases of MUC5AC. These data suggest that IL-4 induced caveolin-1containing lipid rafts aggregation which contributed to MUC5AC synthesis.

\section{Discussion}

In this study, we provided substantial evidence linking asthmatic cytokine IL-4 and airway epithelial cells MUC5AC overproduction. Our additional data revealed that MUC5AC proteins were over-expressed in asthmatic rat airway epithelial cells in vivo (Additional file 1). We found that IL-4 induced caveolin-1-containing lipid rafts aggregation, and co-localization with TRPC1 in the lipid rafts domain. Disruption of lipid rafts or blocking of TRPC1 attenuated IL-4 induced calcium signals and NF- $\mathrm{kB}$ activation, consequently prevented MUC5AC over-expression. Thus, these observations indicated that IL-4 induced MUC5AC overproduction

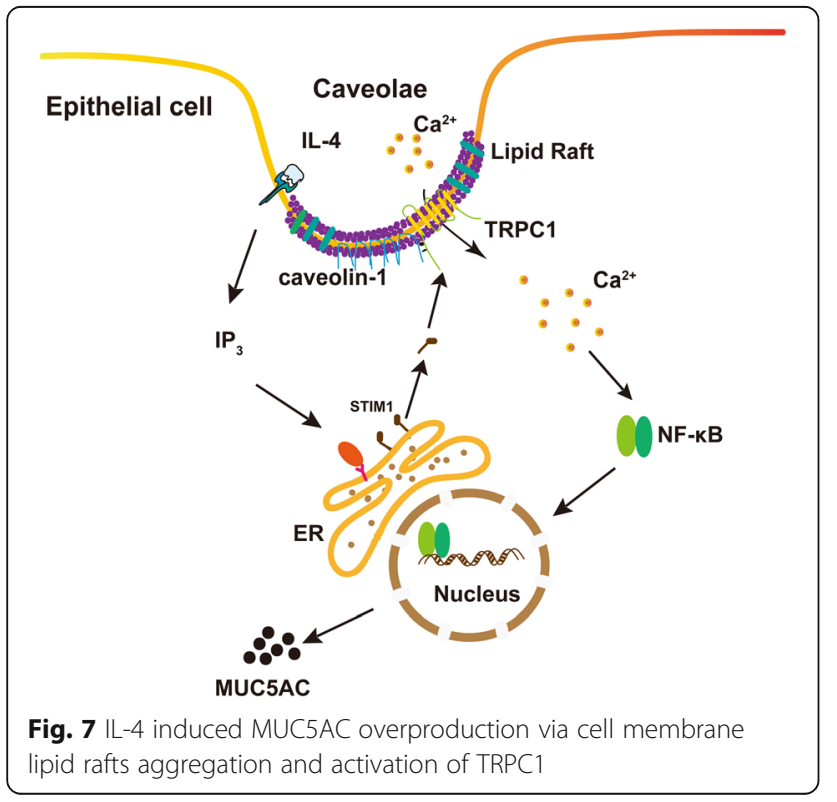

via cell membrane lipid rafts aggregation and activation of TRPC1 (Fig. 7).

In the current study, firstly we found IL-4 induced $\mathrm{Ca}^{2}$ + influx and MUC5AC overproduction in BECs which prevented by 2 -APB. Because 2-ABP is nonspecific and blocks both TRP channels and IP3R, to distinguish between extracellular and intracellular $\mathrm{Ca}^{2+}$ source, we depleted extracellular $\mathrm{Ca}^{2+}$ using EGTA and found extracellular $\mathrm{Ca}^{2+}$ influx played a role in IL-4 induced MUC5AC expression. We next found NF- $\mathrm{kB}$ rather than STAT6 activation mediated IL-4-induced MUC5AC protein synthesis.

For the first time, we found that IL-4 induced caveolin-1-containing lipid rafts aggregation in BECs. Membrane lipid rafts are highly ordered membrane domains that are enriched in cholesterol, sphingolipids and gangliosides, and function as platforms for the recruitment of signaling proteins to facilitate protein-protein interaction and signal transduction. An increasing number of proteins involved in signal transduction have been found to locate in these ordered membrane domains. It is well known that lipid rafts organize receptors, ion channels and their downstream acting molecules to regulate intracellular signaling pathways [28-30].

Recent studies have demonstrated that lipids rafts also contribute to the organization and function of $\mathrm{Ca}^{2+}$ signaling microdomains. TRPC1 channelosome responsible for SOCE is located in caveolar lipid raft domains [18, 31-33]. Destabilization of the caveolar lipid raft domains by $\mathrm{M}$ $\beta C D$ treatment or deletion of caveolin-1 prevents SOCE activation [20, 34]. Caveolin-1 gene knockout disrupts TRPC1-STIM1-Orai1 complex [35]. In the current study, we demonstrated that IL-4 induced TRPC1 co-localization with caveolin-1-containing lipid rafts aggregation, which mediated $\mathrm{Ca}^{2+}$ influx in BECs.

Calcium signal was observed to be related with NF- $\mathrm{kB}$ activation. Sequence analyses of MUC5AC promoter revealed the presence of NF- $\mathrm{KB}$ response elements within it [36]. NF- $\mathrm{kB}$ activity is crucial for mucus production 
[37] . Zhu et al. have reported that $\mathrm{Ca}^{2+}$ oscillation frequency regulated NF- $\mathrm{KB}$ transcriptional activity via increased cumulated $\mathrm{Ca}^{2+}$ spike duration $[38,39]$. Our data showed here that IL-4 induced single calcium peak, blocking TRPC1 with 2-APB prevented calcium signal and suppressed NF- $\mathrm{kB}$ activity. These data suggest that IL-4 induced calcium signaling through caveolin-1containing-lipid-rafts/TRPC1 pathway that resulted in NF- $\mathrm{kB}$ activation and MUC5AC over-production.

\section{Conclusion}

In the current study, we found IL-4 caused aggregation of caveolin-1-containing lipid rafts which activated TPRC1, subsequently activated calcium signal and NF$\kappa \mathrm{B}$, and finally increased MUC5AC synthesis in BECs. This study elucidates a new mechanism underlying asthmatic cytokines induce mucus overproduction, which may be beneficial in developing novel strategies for the treatment of asthma.

\section{Additional file}

Additional file 1: Online supplementary data. (PDF 316 kb)

\author{
Abbreviations \\ $\left[\mathrm{Ca}^{2+}\right]_{\mathrm{i}}$ : intracellular $\mathrm{Ca}^{2+}$; 2-APB: 2-Aminoethyl diphenylborinate; \\ BECs: Bronchial epithelial cells; EGTA: Ethylene glycol tetraacetic acid; IL- \\ 4: Interleukin-4; IP3R: Inositol triphosphate receptor; M- $\beta C D$ : Methyl- $\beta$ - \\ cyclodextrin; SOCE: Store-operated $\mathrm{Ca}^{2+}$ entry; Th2: T helper type 2 cells; \\ TRPC1: Transient receptor potential canonical 1
}

\section{Acknowledgments}

We thank all members from Key Laboratory of Respiratory Diseases, Ministry of Health of China (Wuhan Hubei, China) for their invaluable help. Present affiliation of Shan-Shan Rao: Department of Pathology, the Central Hospital of Wuhan.

\section{Funding}

This work was supported in part by grants from the National Natural Science Foundation of China (No. 81570087, 30770943 to HY; No. 81600071 to LX; No. 81573485,81370186 to WLM; No. 81200020 to PCC).

\section{Availability of data and materials}

Essential datasets supporting the conclusion are included in this published article.

\section{Authors' contributions}

YX, PCC and HY designed the study; YX, PCC, FY, LX and SSR performed experiments; XLH, FC and XPY analyzed the data; WLM and HY wrote the manuscript. All authors read and approved the final manuscript.

\section{Ethics approval and consent to participate}

In the current study, bronchial epithelial cells were isolated from large bronchial airway of rat. The experiments were performed in accordance with the Guide for the Care and Use of Laboratory Animals and approved by the Institutional Animal Care and Use Committee (IACUC) of the Tongji Medical College, Huazhong University of Science and Technology.

\section{Consent for publication}

Not applicable.

\section{Competing interests}

The authors declare that they have no competing interests.

\section{Publisher's Note}

Springer Nature remains neutral with regard to jurisdictional claims in published maps and institutional affiliations.

\section{Author details}

${ }^{1}$ Department of Pathophysiology, School of Basic Medicine, Tongji Medical College, Huazhong University of Science and Technology, Wuhan, Hubei 430030, China. ${ }^{2}$ Department of Clinical Laboratory, Union Hospital, Tongji Medical College, Huazhong University of Science and Technology, Wuhan, Hubei, China. ${ }^{3}$ Department of Respiratory and Critical Care Medicine, Union Hospital, Tongji Medical College, Huazhong University of Science and Technology, Wuhan, Hubei, China. ${ }^{4}$ Department of Forensic Medicine, Nanjing Medical University, Nanjing, Jiangsu, China. ${ }^{5}$ Department of Immunology, School of Basic Medicine, Tongji Medical College, Huazhong University of Science and Technology, Wuhan, Hubei, China. ${ }^{6}$ Key Laboratory of Pulmonary Diseases, Ministry of Health of China, Wuhan, Hubei, China.

Received: 29 December 2016 Accepted: 13 September 2017

Published online: 20 September 2017

\section{References}

1. Rose MC, Voynow JA. Respiratory tract mucin genes and mucin glycoproteins in health and disease. Physiol Rev. 2006;86:245-78.

2. Lai H, Rogers DF. New pharmacotherapy for airway mucus hypersecretion in asthma and COPD: targeting intracellular signaling pathways. J Aerosol Med Pulm Drug Deliv. 2010;23:219-31.

3. Ordonez $\mathrm{CL}$, Khashayar R, Wong HH, Ferrando R, Wu R, Hyde DM, et al. Mild and moderate asthma is associated with airway goblet cell hyperplasia and abnormalities in mucin gene expression. Am J Respir Crit Care Med. 2001; 163:517-23.

4. Muehling LM, Lawrence MG, Woodfolk JA. Pathogenic CD4+ T cells in patients with asthma. J Allergy Clin Immunol. 2017; https://doi.org/10.1016/j. jaci.2017.02.025. [Epub ahead of print]

5. Kim CH, Kim KE, Yoon JH, Song KS. Upregulation of MUC5AC gene expression by IL-4 through CREB in human airway epithelial cells. J Cell Biochem. 2009;108:974-81.

6. Sato K, Yamamoto H, Nomura T, Matsumoto I, Miyasaka T, Zong T, et al. Cryptococcus Neoformans infection in mice lacking type I interferon signaling leads to increased fungal clearance and IL-4-dependent Mucin production in the lungs. PLoS One. 2015;10:e0138291.

7. Temann UA, Prasad B, Gallup MW, Basbaum C, Ho SB, Flavell RA, et al. A novel role for murine IL-4 in vivo: induction of MUC5AC gene expression and mucin hypersecretion. Am J Respir Cell Mol Biol. 1997;16:471-8.

8. Kang JH, Hwang SM, Chung IY. S100A8, S100A9 and S100A12 activate airway epithelial cells to produce MUC5AC via extracellular signalregulated kinase and nuclear factor-kappaB pathways. Immunology. 2015;144:79-90.

9. Liu C, Weir D, Busse P, Yang N, Zhou Z, Emala C, et al. The flavonoid 7,4'Dihydroxyflavone inhibits MUC5AC gene expression, production, and secretion via regulation of NF-kappaB, STAT6, and HDAC2. Phytother Res. 2015;29:925-32.

10. Xie T, Luo G, Zhang Y, Wang X, Wang X, Wu M, et al. Rho-kinase inhibitor fasudil reduces allergic airway inflammation and mucus hypersecretion by regulating STAT6 and NFkappaB. Clin Exp Allergy. 2015;45:1812-22.

11. Fujisawa T, Chang MM, Velichko S, Thai P, Hung LY, Huang F, et al. NFkappaB mediates IL-1 beta- and IL-17A-induced MUC5B expression in airway epithelial cells. Am J Respir Cell Mol Biol. 2011;45:246-52.

12. Fujisawa T, Velichko $S$, Thai $P$, Hung LY, Huang F, Wu R. Regulation of airway MUC5AC expression by IL-1 beta and IL-17A; the NF-kappaB paradigm. J Immunol. 2009;183:6236-43.

13. Quinlan KL, Naik SM, Cannon G, Armstrong CA, Bunnett NW, Ansel JC, et al. Substance $P$ activates coincident NF-AT- and NF-kappa B-dependent adhesion molecule gene expression in microvascular endothelial cells through intracellular calcium mobilization. J Immunol. 1999;163:5656-65.

14. Zhu L, Luo Y, Chen T, Chen F, Wang T, Hu Q. Ca2+ oscillation frequency regulates agonist-stimulated gene expression in vascular endothelial cells. J Cell Sci. 2008;121:2511-8.

15. Hong JH, Li Q, Kim MS, Shin DM, Feske S, Birnbaumer L, et al. Polarized but differential localization and recruitment of STIM1, Orai1 and TRPC channels in secretory cells. Traffic. 2011;12:232-45. 
16. Liu X, Cheng KT, Bandyopadhyay BC, Pani B, Dietrich A, Paria BC, et al. Attenuation of store-operated $\mathrm{Ca} 2+$ current impairs salivary gland fluid secretion in TRPC1(-/-) mice. Proc Natl Acad Sci U S A. 2007;104:17542-7.

17. Singh BB, Zheng C, Liu X, Lockwich T, Liao D, Zhu MX, et al. Trp1dependent enhancement of salivary gland fluid secretion: role of storeoperated calcium entry. FASEB J. 2001;15:1652-4.

18. Pani B, Ong HL, Liu X, Rauser K, Ambudkar IS, Singh BB. Lipid rafts determine clustering of STIM1 in endoplasmic reticulum-plasma membrane junctions and regulation of store-operated Ca2+ entry (SOCE). J Biol Chem. 2008;283:17333-40.

19. Galan C, Woodard GE, Dionisio N, Salido GM, Rosado JA. Lipid rafts modulate the activation but not the maintenance of store-operated $\mathrm{Ca}(2+)$ entry. Biochim Biophys Acta. 1803;2010:1083-93.

20. Brazer SC, Singh BB, Liu X, Swaim W, Ambudkar IS. Caveolin-1 contributes to assembly of store-operated $\mathrm{Ca} 2+$ influx channels by regulating plasma membrane localization of TRPC1. J Biol Chem. 2003;278:27208-15.

21. Isshiki M, Anderson RG. Function of caveolae in Ca2+ entry and Ca2+ -dependent signal transduction. Traffic. 2003:4:717-23.

22. Yeh YC, Parekh AB. Distinct structural domains of caveolin-1 independently regulate $\mathrm{Ca} 2+$ release-activated $\mathrm{Ca} 2+$ channels and $\mathrm{Ca} 2+$ microdomaindependent gene expression. Mol Cell Biol. 2015;35:1341-9.

23. Yeh YC, Tang MJ, Parekh AB. Caveolin-1 alters the pattern of cytoplasmic $\mathrm{Ca} 2+$ oscillations and $\mathrm{Ca} 2+-$ dependent gene expression by enhancing leukotriene receptor desensitization. J Biol Chem. 2014;289:17843-53.

24. Aikawa T, Shimura S, Sasaki H, Ebina M, Takishima T. Marked goblet cell hyperplasia with mucus accumulation in the airways of patients who died of severe acute asthma attack. Chest. 1992;101:916-21.

25. Laoukili J, Perret E, Willems T, Minty A, Parthoens E, Houcine O, et al. IL-13 alters mucociliary differentiation and ciliary beating of human respiratory epithelial cells. J Clin Invest. 2001;108:1817-24.

26. Yan F, Li W, Zhou H, Wu Y, Ying S, Chen Z, et al. Interleukin-13-induced MUC5AC expression is regulated by a PI3K-NFAT3 pathway in mouse tracheal epithelial cells. Biochem Biophys Res Commun. 2014;446:49-53.

27. Jin S, Tian D, Chen JG, Zhu LP, Liu SY, Wang DX. Passive sensitization increases histamine-stimulated calcium signaling and NF-kappaB transcription activity in bronchial epithelial cells. Acta Pharmacol Sin. 2006;27:708-14.

28. Hryniewicz-Jankowska A, Augoff K, Biernatowska A, Podkalicka J, Sikorski AF. Membrane rafts as a novel target in cancer therapy. Biochim Biophys Acta. 1845;2014:155-65

29. Lorent JH, Levental I. Structural determinants of protein partitioning into ordered membrane domains and lipid rafts. Chem Phys Lipids. 2015;192:23-32.

30. Mollinedo F, Gajate C. Lipid rafts as major platforms for signaling regulation in cancer. Adv Biol Regul. 2015:57:130-46.

31. Alicia S, Angelica Z, Carlos S, Alfonso S, Vaca L. STIM1 converts TRPC1 from a receptor-operated to a store-operated channel: moving TRPC1 in and out of lipid rafts. Cell Calcium. 2008;44:479-91.

32. Gueguinou M, Gambade A, Felix R, Chantome A, Fourbon Y, Bougnoux P, et al. Lipid rafts, $\mathrm{KCa} / \mathrm{ClCa} / \mathrm{Ca} 2+$ channel complexes and EGFR signaling: novel targets to reduce tumor development by lipids? Biochim Biophys Acta. 1848;2015:2603-20.

33. Ong HL, Ambudkar IS. The dynamic complexity of the TRPC1 channelosome. Channels (Austin). 2011:5:424-31.

34. Lockwich TP, Liu X, Singh BB, Jadlowiec J, Weiland S, Ambudkar IS. Assembly of Trp1 in a signaling complex associated with caveolin-scaffolding lipid raft domains. J Biol Chem. 2000;275:11934-42.

35. Pani B, Liu X, Bollimuntha S, Cheng KT, Niesman IR, Zheng C, et al. Impairment of TRPC1-STIM1 channel assembly and AQP5 translocation compromise agoniststimulated fluid secretion in mice lacking caveolin1. J Cell Sci. 2013;126:667-75.

36. Chen Y, Nickola TJ, DiFronzo NL, Colberg-Poley AM, Rose MC. Dexamethasone-mediated repression of MUC5AC gene expression in human lung epithelial cells. Am J Respir Cell Mol Biol. 2006;34:338-47.

37. Van Seuningen I, Pigny P, Perrais M, Porchet N, Aubert JP. Transcriptional regulation of the 11 p15 mucin genes. Towards new biological tools in human therapy, in inflammatory diseases and cancer? Front Biosci. 2001;6:D1216-34.

38. Song $\mathrm{S}$, Li J, Zhu L, Cai L, Xu Q, Ling C, et al. Irregular Ca(2+) oscillations regulate transcription via cumulative spike duration and spike amplitude. J Biol Chem. 2012;287:40246-55.

39. Zhu L, Song S, Pi Y, Yu Y, She W, Ye H, et al. Cumulated Ca2(+) spike duration underlies Ca2(+) oscillation frequency-regulated NFkappaB transcriptional activity. J Cell Sci. 2011;124:2591-601.

\section{Submit your next manuscript to BioMed Central and we will help you at every step:}

- We accept pre-submission inquiries

- Our selector tool helps you to find the most relevant journal

- We provide round the clock customer support

- Convenient online submission

- Thorough peer review

- Inclusion in PubMed and all major indexing services

- Maximum visibility for your research

Submit your manuscript at www.biomedcentral.com/submit
Biomed Central 